Tema: Tillid

\title{
Sproglig mikrotilfid
}

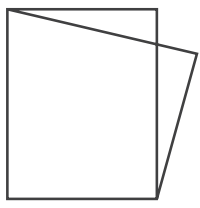

Ole Togeby, professor, Institut for Kommunikation og Kultur, Aarhus Universitet
Når vi kommunikerer og deler tanker med hinanden ved hjælp af sproglige ytringer og tekster, sker det kun fordi vi samarbejder om det. Og samarbejde kræver tillid til at samarbejdspartneren udfører sin del af opgaven. Selv om vi igen og igen bliver skuffet når vi tror på hvad folks siger, forudsætter vi altid allerede at den anden samarbejder om at dele tanker næste gang. Denne sproglige mikrotillid er ofte kontrafaktisk, men det er alligevel det, der får kommunikationen til at virke og får samfundet til at hænge sammen.

\section{Hvad er tillid?}

Tillid siges at være en del af en Volkswagen. Det fremgår af følgende helsidesannonce fra Volkswagen, da det i oktober 2015 blev afsløret at deres dieselbiler forurener 7 gange mere end de må efter de gældende miljøregler. Dette faktum blev dog skjult ved at bilerne havde installeret et computerprogram der kunne registrere når bilen blev testet i et laborato- rium, og ved disse lejligheder ændrede motorgangen så den ikke forurenede mere end den måtte. Men når den ikke forurenede, brugte den mere brændstof og havde færre hestekræfter end når den forurenede, og et effektivt filter ville koste 10.000 kr. per bil. Volkswagen snød i testen for at sælge flere biler. Og da det blev opdaget og skandalen rullede, satte koncernen følgende helsidesannonce i aviserne:

Vi har ødelagt den vigtigste del i vores biler: jeres tillid.

For nylig har vi begået en stor fejl, vi har brudt jeres tillid. I 60 år har I haft tillid til vores pålidelighed. Hver gang I har købt en bil af os, har I troet på os. Alligevel har vi svigtet jer.

Vi ved nu bedre end nogensinde, at handling er vigtigere end ord. Vi vil løse situationen for alle berørte kunder. Det siger sig selv, at sagen rejser en lang række spørgsmål. lkke mindst fra 


\section{Tillid er dog ikke blot en individuel følelse; tillid er det der gør interaktion mellem mennesker mulig og făr samfundet til at hænge sammen i et netværk af aftaler, forpligtelser og rettigheder.}

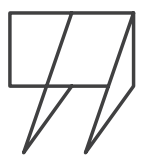

alle jer, som er Volkswagen-ejere. Og vi ville ønske, at vi kunne svare nu.

De rigtige svar i denne sag kræver tid. Alt skal frem i lyset og det er grundighed og ikke hurtighed, der kommer i første række.

Vi er startet her: vwdielselinfor.dk Og vi stopper ikke, før vi har genvundet jeres tillid.

Tillid er selvfølgelig i virkeligheden ikke en dims i en Volkswagen, men noget som i ordbogen (Den Danske Ordbog) defineres som en stærk følelse: "'Tillid' er en stærk følelse af at kunne tro på, stole på eller regne med nogen eller noget". Tillid er dog ikke blot en individuel følelse; tillid er det der gør interaktion mellem mennesker mulig og får samfundet til at hænge sammen i et netværk af aftaler, forpligtelser og rettigheder. Vi havde således tillid til at en dieselbil både kan være billig, brændstoføkonomisk og med mange hestekræfter og samtidig overholde miljøkravene. Men det kan den ikke.

\section{Samarbejde}

Det brud på tillid som sagen om Volkswagen er et eksempel på, drejer sig om tillid mellem aktører der har udstedt løfter og indgået kontrakter, men tillid spiller også en rolle hver eneste gang vi kommunikerer vores tanker ved hjælp af en sproglig sætning, som i $\mathrm{fx}$ annoncen ovenfor. Vi kan nemlig kun kommunikere og dele tanker med hinanden ved hjælp af sproglige ytringer og tekster, hvis vi samarbejder om det. Og samarbejde kræver tillid til at samarbejdspartneren udfører sin del af den fælles opgave. Lad os kalde denne tillid som forudsættes mellem parterne i hver eneste sproglige ytring, for sproglig mikrotillid.

Det som den sproglige mikrotillid er tillid til, er beskrevet af den engelskamerikanske filosof Paul Grice som samarbejdsprincippet, der lyder således:
“Lav dit kommunikative indlæg som det fordres, på det stadium hvor det forekommer, med det formål eller retning som er accepteret for den meningsudveksling som du indgår i" (Grice 1975). Det er så udmøntet i fire maksimer om tydelighed, sandfærdighed, relevans, og informativitet. Vi har således tillid til 1) at ytringen er udtrykt klart, tydeligt og ordentligt, således at den ikke kan misforstås eller vildlede adressaterne. Vi har tillid til 2) at afsenderen af et udsagn er sandfærdig, dvs. selv tror på det og ikke mangler passende evidens for at det er sandt. Vi har tillid til 3) at det der kommunikeres, er relevant i forhold til de aktuelle modtageres interesser, dvs. at afsenderens sproglige handling passer til modtagernes situation som nøglen $\mathrm{i}$ en lås. Vi har tillid til 4) at der i ytringen er netop så mange informationer som er nødvendige, og ikke flere end at de netop er tilstrækkelige til det aktuelle formål. Det skal her vises hvorledes ytringen 

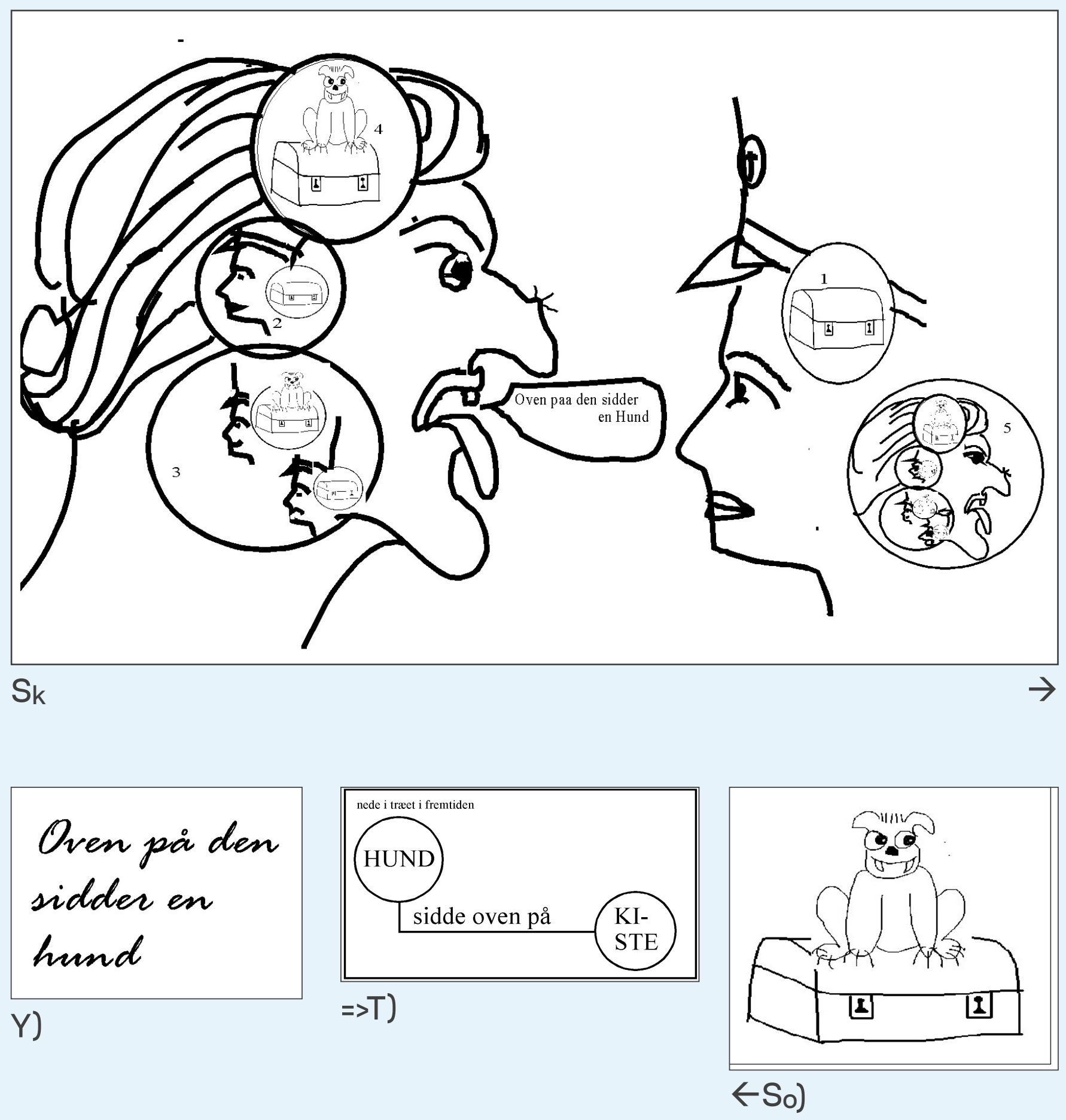
Sproglig mikrotillid

af en enkelt udvalgt sætning, nemlig sætningen oven på den sidder en hund, overholder alle fire maksimer. For at vise det må man beskrive en hel situation, og ikke blot af ytringen. Sådan en hel situation findes i H.C. Andersens eventyr Fyrtøjet der begynder således:

Der kom en Soldat marcherende henad Landeveien; een, to! een, to! han havde sit Tornister paa Ryggen og en Sabel ved Siden, for han havde været i Krigen, og nu skulle han hjem. Saa mødte han en gammel Hex paa Landeveien; (...) Hun sagde: "god Aften, Soldat! 13/ hvor Du har en pæn Sabel og et stort Tornister, 14/ Du er en rigtig Soldat! 15/ Nu skal Du faae saa mange Penge, Du vil eie!" "Tak skal du have, din gamle Hex!" sagde Soldaten. "Kan Du see det store Træ?" sagde Hexen, og pegede paa et Træ, der stod ved Siden af dem. "Det er ganske huult inden i! Der skal Du krybe op i Toppen, saa seer Du et Hul, som Du kan lade dig glide igjennem og komme dybt i Træet! Jeg skal binde dig en Strikke om Livet, for at jeg kan heise Dig op igjen, naar Du raaber paa mig!" "Hvad skal jeg saa nede i Træet?" 25/ spurgte Soldaten. "Hente Penge!" sagde Hexen, "Du skal vide, naar Du kommer ned paa Bunden af Træet, saa er Du i en stor Gang, der er ganske lyst, for der brænde over hundrede Lamper. Saa seer Du tre Døre, Du kan lukke dem op, Nøglen sidder i. Gaaer Du ind i det første Kammer, da seer Du midt paa Gulvet en stor Kiste, oven paa den sidder en Hund;

Som et eksempel på hvorledes Grices maksimer virker, skal her den sidste sætning, oven på den sidder en Hund, analyseres (Togeby 2003). Der er i eksemplet følgende instanser i aktion: kommunikationssituationen på landevejen ved det gamle træ med personerne og deres bevidstheder $\left(S_{k}\right)$. Her sker der den begivenhed at heksen ytrer nogle ord $(Y)$. Denne ytring opfattes af soldaten og fremkalder en tanke $(T)$, som i en eller anden forstand er den samme tanke, som den heksen har inde i sit, nemlig en tanke om (som er rettet mod) den omtalte situation ( $\mathrm{S}_{\mathrm{o}}$ ), hvor hunden (nede under jorden) sidder oven på kisten.

Forholdet mellem disse fire instanser er dette at kommunikationssituationen $\left(S_{k}\right)$ kausalt (fysiologisk) fremkalder (noteret ' $\rightarrow$ ') et sanseindtryk hos parterne der indgår i den; de sanser hele situationen, men fokuserer begge på selve ytringshandlingen på baggrund af personerne og omgivelserne. Denne ytring $(Y)$ tæller som (noteret ' $=>$ ') en tanke ( $T$ ) om (noteret $\leftarrow$ ) den omtalte situation (So), fordi den har sprogfællesskabet og kommunikationssituationen som fælles baggrund (noteret ' [... ] $\mathrm{B}^{\prime}$ ). Det hele kan noteres i én formel således:

$\mathrm{S}_{\mathrm{k}} \rightarrow\left[\mathrm{Y}=>\left(\mathrm{T} \leftarrow \mathrm{S}_{\mathrm{o}}\right)\right] \mathrm{B}$.

Kommunikationssituationen $\left(S_{k}\right)$ fremkal$\operatorname{der}(\rightarrow)$ hos begge parter den opfattelse ([...]) at ytringen $(Y)$ i deres sprogfællesskab (B) tæller som $(\Leftrightarrow)$ den tanke $(\mathrm{T})$ at $(\leftarrow)$ en hund sidder på kisten (So).

Det er en vigtig forudsætning for kommunikationen at ytringen kun kan tælle som en fælles tanke på baggrund af parternes fælles opfattelse af kommunikationssituationen; de tilhører det samme sprogfællesskab og kender det samme sprog, de går ud fra at de ser den samme virkelighed omkring sig (Kan du se det store trœ? siger heksen), og de anerkender begge hvem der taler, og hvem der lytter, hvad der er fokus, og hvad der er baggrunden i situationen: [Y => T]B. Tanken er om den omtalte situation; tankens indhold er ikke heksen på landevejen, men hunden på kisten. Denne "omhed" eller rettethed noteres ' $\leftarrow$ ' (altså som baglæns kausalitet) fordi tanken som soldaten får ved at høre heksens ytring, er af en sådan art at den kunne være kausalt fremkaldt af at han stod nede i træet, gik ind ad døren, og så hunden sidde på kisten (hvad han faktisk gør senere i historien). Tankens rettethed (dens intentionalitet) er altså en spejlrelation til det at den fysiske virkelighed kausalt fremkalder sanseindtryk. Den tanke om hunden på kisten som fremkaldes af heksens ytring, er den samme tanke som den virkelige hund på kisten ville fremkalde hvis soldaten stod nede i rummet i det hule træ og så på den: $\left(T \leftarrow S_{0}\right)$.

Det kan nu beskrives hvorledes Grices fire maksimer er blevet overholdt i dette tilfælde. Sætningen overholder maksimen om formens tydelighed: den er korrekt syntaktisk udformet og signalerer tydeligt at det vigtige ikke er at det er en hund der sidder på kisten (i så fald skulle der have stået oven på den sidder der en hund), men at der er noget der hindrer at man kan åbne kisten. Det semantiske krav om sandfærdighed er også overholdt. Da soldaten senere kommer ned $\mathrm{i}$ det hule træ, sidder der faktisk en hund, og heksen ved det fordi hun har fået det at vide af sin bedstemor. Det pragmatiske krav om relevans er overholdt. Det er nemlig i soldatens interesse at få at vide at der sidder en hund på kisten, fremfor ikke at vide det, for han er interesseret $i$ at hente de penge som ligger nede $i$ kisten, og hvis der sidder en hund på kisten kan han ikke få pengene. Heksen fortsætter så:

... oven paa den sidder en Hund; han har et Par Øine saa store som et 
Tema: Tillid

Par Theekopper, men det skal Du ikke bryde Dig om! Jeg giver dig mit blaatærnede Forklæde, det kan Du brede ud paa Gulvet; gaae saa rask hen og tag Hunden, sæt ham paa mit Forklæde, luk Kisten op og tag ligesaa mange Skillinger, Du vil.

Hvis soldaten ikke havde fået at vide at der sad en hund, ville han jo ikke kunne forstå hvad han skulle bruge forklædet til. Den handling at heksen oplyser at oven på den sidder en hund er således yderst relevant i forhold til soldatens interesser $\mathrm{i}$ at hente penge.

Endelig er den fjerde maksime også overholdt. Den siger at der hverken må gives for meget eller for lidt information i forhold til det aktuelle formål. Hvis heksen kun havde sagt at der var noget tungt oven på kistens låg, ville soldaten ikke have forudsætninger for senere at forstå at det blåternede forklæde var nødvendigt for at man kunne fjerne denne hindring, og hvis heksen havde sagt: oven på kisten sidder der en buldog, ville hun have fokuseret på oplysninger som ikke var nødvendige for soldaten; det er jo ligegyldigt for ham af hvad race hundene er. Hun siger ganske vist at hunden har øjne så store som tekopper, men det er jo for at han kan kende den fra hundene i de næste to rum, og heksen siger også udtrykkeligt at han ikke skal tage sig af det; det er altså parentetisk information.

Så man kan konstatere at alle fire maksimer er overholdt idet ytringen af sætningen oven paa den sidder en Hund både er tydelig, sandfærdig, relevant og passende informativ.

\section{Tillid til informativiteten}

Man kan i endnu finere detaljer beskrive situationen hvor heksen netop skal til at sige sætningen på følgende måde. At den er formuleret tydeligt nok, kan man se af at soldaten forstår at pronominet den henviser til den kiste som var introduceret i den foregående sætning (noteret ved 1 på tegningen $S_{k}$ ). Det går heksen ud fra idet hun med ordet den forudsætter det (noteret 2). Heksen går også ud fra at det er relevant for soldaten at få et vide at der er en hund på kisten frem for ikke at få det at vide - når det nu er sandt at der faktisk er en hund på kisten, der nede under jorden (4). Relevansen kan illustreres ved at heksen tænker at hvis soldaten tænker at der er en hund på kisten, bliver han glad og tilfreds, mens han er tvær og utilfreds hvis han ikke ved det (3).

Dette sidste trin er imidlertid ikke indlysende, for soldaten kan jo ikke vide at han senere vil få at vide at han får et blåternet forklæde som han kan flytte hunden over på uden at den gør ham noget. Så det er kun heksen der ved at oplysningen om hunden på kisten vil blive relevant for soldaten når han senere har fået det blåternede forklæde; soldaten kan på dette tidspunkt ikke selv vide det og kan altså ikke erkende relevansen af ytringen.

Så når soldaten alligevel hører efter hvad heksen siger til ham, som om det var informativt, er det fordi han har tillid til at det som information er nødvendigt for at han kan hente pengene selv om han på dette tidspunkt ikke selv forstår hvordan. Heksen har lovet ham pengene, og soldaten har nu tillid til at oplysningen om hunden på kisten er nødvendig information for dette formål med samtalen. Her er der altså tale om at modtageren har tillid til at afsenderen i hver eneste sætning overholder det maksime som siger at der i ytringen er netop så mange informationer som er tilstrækkelige, og ikke flere end at de er nødvendige til det aktuelle formål. Det er den sproglige mikrotillid. Denne tillid er illustreret på tegningen som (5) ved at soldaten tænker at heksen tænker at informationen om hunden på kisten er relevant for ham. Soldaten kan kun forstå hvad heksen siger hvis han har tillid til at hun kun siger det som er nødvendigt for at det skal være i hans interesse at bruge tid og energi på at forstå hvad hun siger. Når han fortsætter med at lytte, er det tillid til at han, når heksen er færdig med at tale, har fået nytte af de informationer som han på det aktuelle sted i teksten ikke har kunnet forstå relevansen af. Han kan altså, når han hører sætningen oven på den sidder en Hund, se frem til slutningen af hendes replik, hvorfra han vil kunne se tilbage på sætningen, og først da forstå dens relevans for ham. Heksen overholder altså i den analyserede sætning alle fire maksimer til punkt og prikke, og hun holder også det løfte som hun har givet soldaten om at han kan hente penge hvis han også henter det fyrtøj som hendes bedstemor glemte sidst hun var dernede. Men soldaten overholder ikke sin del af aftalen. Da han med heksens hjælp kommer op af træet med alle pengene og fyrtøjet, sker der følgende:

“Hvad vil du med det Fyrtøj?" spurgte Soldaten.

“Det kommer ikke dig ved!" sagde Heksen, "nu har du jo fået pengene! Giv mig nu bare Fyrtøjet!" “Sniksnak!" sagde Soldaten. Vil du straks sige mig, hvad du vil med det, eller jeg trækker min Sabel ud og hugger dit Hoved af!" “Nej, " sagde Heksen. Saa huggede Soldaten Hovedet af hende. Der laa hun! 
Sproglig mikrotillid

Og sådan går det også i den virkelige verden; vi bliver tit skuffet når vi har tillid til at vores medmennesker holder deres løfter og aftaler. Heksen bliver skuffet i sin tillid til at soldaten vil holde den aftale de har indgået, og aflevere fyrtøjet når han nu har fået pengene. Man kan sige at soldaten svigter den makrotillid som heksen nærer til ham. Men ikke desto mindre nærer hun stadig mikrotillid til at hun kan overbevise ham ved argumenter: nu har du jo faaet Pengene!, og at hun kan sige Nej til at fortælle hvad hun vil med fyrtøjet. Selv om soldaten ikke er makrotilliden værdig, kan man stole på ham på mikroplan; når han truer med at hugge hovedet af hende, gør han det også når hans betingelse ikke er opfyldt.

Kontrafaktisk tillid og underforståelser Grices fire maksimer er alle underordnet det generelle samarbejdsprincip at man skal forme sit indlæg som det fordres $i$ den særlige situation som man er i. Så selv om et enkelt maksime brydes, kan modtagerne godt antage at afsenderen har brudt det for i en særlig situation alligevel at samarbejde på den mest hensigtsmæssige måde.

Hvis en professor skal skrive en anbefaling til en ikke særlig dygtig student som søger ansættelse til at udføre noget akademisk arbejde, kan hun fx skrive således:

Til rette vedkommende.

Student NN deltager ofte i timerne, han udtaler sig gerne om filosofiske emner, og hans stemme er høj og kraftig.

Venlig hilsen

Professoren er både tydelig, sandfærdig og informativ, men oplysningerne er ikke relevante. I genren "en anbefaling" er formålet imidlertid at beskrive alle de egenskaber ved personen som er relevante for at udfylde en stilling, og så kan man ikke rive at NN ikke har forstået ret meget af stoffet og er dumpet flere gange. Derfor overholder professoren faktisk inden for genrens rammer samarbejdsprincippet, nemlig ved sandfærdigt og informativt at beskrive alle NNs relevante egenskaber. Modtagerne kan så ræsonnere som så: hvis det er alle de relevante egenskaber, er NN ikke kvalificeret til stillingen. Denne form for kommunikation kalder Grice implicature, og det oversætter jeg til underforståelse. Professoren valgte at bryde et af maksimerne, for i stedet at samarbejde om at kommunikere ved en underforståelse.

Et andet eksempel på underforståelse ved samarbejdende maksimebrud er metaforer. Når der i Volkswagensreklamen står: Vi har ødelagt den vigtigste del $i$ vores biler: jeres tillid, er det et brud på sandfærdighedsmaksimet, for tillid er ikke en fysisk del af en Volkswagen. Men vi har tillid til at afsenderne, selv om de bryder et enkelt maksime, alligevel samarbejder. Vi forstår derfor at de nok snarere vil kommunikere til os at en Volkswagen er andet og mere end en bil, nemlig en livsstil som vi har sammen med bilproducenten. Det at vi godt forstår hvad de mener, selv om vi ved at det er noget sludder, er blevet kaldt barmhjertighedsprincippet, men det er ikke lutter barmhjertighed, det skyldes at vi har mikrotillid til at afsenderen overholder det generelle samarbejdsprincip, selv om et enkelt maksime er blevet brudt.

Alternativet til at have denne tillid er vold eller afbrydelse af samtalen. Når soldaten forstår at heksen ikke vil fortælle hvad hun skal med fyrtøjet, hugger han med vold hovedet af hende. Jeg vil her give et eksempel at man afbryder kommunikationen ved at fortælle om en episode som jeg selv har oplevet i 1970 nord for byen Shiraz i Iran. Jeg var sammen med nogle venner taget med bus ud til en landsby der lå tæt ved ruinerne af Persepolis, kongebyen i det antikke Persien. Vi var stået af bussen og skulle finde frem til Persepolis, som dengang ikke var markeret som en turistattraktion. Jeg spurgte en mand på gaden om vejen til ruinerne. Han forklarede derpå, meget omstændeligt ved at pege og tegne et kort i sandet, at vi skulle gå ca. to kilometer ud ad en vej mod vest, og så ved en rød minaret dreje til højre og gå ca. 1.5 kilometer til en bakke med en bevoksning, hvorfra vi ville se Persepolis ligge på venstre hånd. Vi gjorde som han havde anvist, og da vi kom frem, stod vi midt i en ørken, og der var ikke nogen ruiner at se nogen steder. Vi gik tilbage og fandt endelig frem til ruinerne, som i virkeligheden lå øst for landsbyen hvor vi var stået af bussen.

Hvad var det der var sket? Jo, manden vidste ikke hvor Persepolis lå. Men han ville ikke være ved at han ikke kunne vise os vejen, og han havde et princip som var stærkere end Grices samarbejdsprincip, nemlig at han i en samtale ikke måtte tabe ansigt over for sådanne udlændinge som os, der var kommet langvejsfra for at se på hans land. Så han foretrak detaljeret at vise os en forkert vej, fremfor at indrømme at han ikke vidste hvor Persepolis lå.

Dette kan opfattes som en slags alternativt samarbejdsprincip hvor maksimet om ikke at tabe ansigt står over maksimerne om meddelelsens tydelighed, sandhed, relevans og informativitet. Da det gik op for os at de fleste mænd i Iran havde denne prioritering, holdt vi op med at spørge om vej, og fandt ved hjælp af kort og verdenshjørner selv vej til de steder vi ville besøge. Vi holdt altså 
Tema: Tillid

\section{I vores eget sprogsamfund, hvor det er en livsbetingelse at kommunikere med sine omgivelser, hverken kan eller vil vi reagere på de mikrotillidsbrud som vi bestandig oplever, ved vold eller ved afbrydelse af samtalen.}

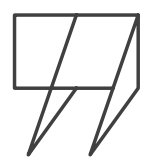

op med at samarbejde om at dele tanker ved hjælp af tegn fordi vi ikke havde tillid til at samtalepartnerne havde de samme formål og regler for informationsudveksling som vi forudsatte. Det ikke-voldelige alternativ til tillidsfuld samarbejde på grundlag af de fire maksimer er altså at afbryde samarbejdet, at holde op med at kommunikere ved hjælp af tegn og tekster.

Det er slet ikke så sjældent vores tillid til andre skuffes. I den politiske debat oplever vi fx ofte at debattører bestandig overtræder samarbejdsprincippet og de fire maksimer. De svarer slet ikke på de stillede spørgsmål, men taler om noget andet, de snakker uden om, de forudsætter det de skulle argumentere for, de dutter folk en mening på hvis vanvid alle kan forstå, de går efter manden i stedet for at gå efter bolden, de generaliserer og opfatter kun i sort og hvidt. Men selv om vi ved at det på denne måde er kontrafaktisk når vi tror på at politikerne samarbejder med os om kommunikation, hører vi dog næste gang alligevel på den politiske debat.

I vores eget sprogsamfund, hvor det er en livsbetingelse at kommunikere med sine omgivelser, hverken kan eller vil vi reagere på de mikrotillidsbrud som vi bestandig oplever, ved vold eller ved afbrydelse af samtalen. I en ny samtalesituation forudsætter vi altid allerede idealet som samarbejde, og netop af denne grund ender kommunikationen med at virke, også selv om den er defekt ved at et maksime overtrædes (Habermas 2001, 153).

Vi fortsætter således med at opretholde i det mindste den mikrotillid som er betingelsen for overhovedet at forstå hinanden, og i mange situationer også makrotilliden til samtalepartneren - selv om vi ved at det som regel er kontrafaktisk. Samtalepartnere er næppe til at stole på i mere end halvdelen af makrotilfældene, og i de fleste sætninger er mikrotilliden blevet misbrugt fordi der er der sket brud på et af de fire maksimer, således at det der skal forstås, ikke er ekspliciteret, men skal underforstås. Og denne underforståelse sker kun fordi vi altid allerede har tillid og forventning til at den anden næste gang overholder idealet som sprogligt samarbejde.

\section{Mikrotillid til Volkswagen}

Vi kan nu vende tilbage til annoncen fra Volkswagen. Den optræder i en situation hvor bilfabrikken bør sige undskyld, men de siger faktisk ikke undskyld. De melder sig nærmest ud af det sproglige samarbejde ved at sige at de ikke kan svare (endnu, hvis det skal være grundigt). Og de slutter med sætningen:

Og vi stopper ikke, før vi har genvundet jeres tillid.

De lover os (eller truer os med) at de ikke stopper (nemlig med at forsøge at kommunikere) indtil de har vundet vores tillid tilbage. Det de skal, er imidlertid 
Sproglig mikrotillid

ikke at tale om vores tillid, men at give en undskyldning. En undskyldning kunne bestå mange forskellige ting: Den kunne bestå i at koncernledelsen fortrød og lovede bod og bedring, eller $i$ at de forklarede hvad der var sket, fx hvordan det lykkedes at snyde i testene. Eller $\mathrm{i}$ at ledelsen hævdede at de var uskyldige fordi det var en konspiration af ingeniører der havde gjort det bag om deres ryg. De kunne også love (og vi ville gerne tro dem) hvorledes de skadelidte bilejere kunne få kompensation, fx ved gratis at få sat et filter på, eller ved at bilerne blev købt tilbage, eller ved at folk fik en anden og bedre bil.

Intet af dette gør Volkswagen i deres kæmpeannonce; de prøver ikke på nogen måde at gøre teksten relevant for os læsere; ikke engang ved underforståelser og metaforer. De trygler om vores tilgivelse og om vores mikrotillid. Men de glemmer at når vi faktisk læser deres annonce, har de allerede altid vores mikrotillid, dvs. vores tillid til at det de siger i annoncen, er tydeligt, sandt, relevant og informativt i forhold til genren en undskyldning. Og det de opnår ved at tvivle på vores mikrotillid, er at miste det eneste de har tilbage, nemlig vores mikrotillid. Jeg holder fra nu af op med som læser at samarbejde om kommunikation med Volkswagen.

\section{REFERENCER}

Grice, Paul 1975: "Logic and conversation" i Cole, I.P., and J.Morgan 1975: Syntax and Semantics, Vol 3. Speech Acts. New York: Academic Press. s. 41-51.

Habermas, Jürgen 2001: “Forberedende bemærkninger til en teori om den kommunikative kompetens" i Henriksen, Carol 2001: Can you reach the salt? Pragmatikkens klassiske tekster. København: Roskilde Universitetsforlag.

Togeby, Ole 2003: Fungerer denne sœtning? Funktionel dansk sproglœre. København: G.E.C. Gads Forlag. 